\title{
Toni Morrosion - The Vitalist: Bio Versus Necro Centricities
}

\section{Kennedy J.}

Senior Lecturer in English

Department of Language

Eastern University

Sri Lanka

kennedyjeevaretnam@gmail.com

Abstract

Toni Morrison, as many think, is a feminist writer or an African-American writer and so on. When we read her novels, she does not confine herself with feminism, or Africanism, or Americanism, or a writer for pleasure reading. Morrison is a serious writer and deals with matters that are universal and each character that she develops speaks about the nature of love, passion, and they all are life-giving.

Morrison gives many oppositional structures in her novels - characters, plots, incidents, and ideologies - to show the readers that the world (and each one of us) is surrounded with so many "opposites" which are inevitable and it is the duty of the human beings to cull the best out of them.

Her characters and themes are life-affirming / life-denying or life-affording / deathdealing or having positive / negative attitudes. However, they all describe that love for oneself and others are the only measure that would make the world move.

Keywords: Toni Morrison, Vitalist, Attitude, Affirming, Denying, Affording, Dealing, Positive, Negative 
Introduction

Toni Morrison says that anyone can get life from anything - it is not merely the survival of the fittest, but also fitting into the survival as well. In the "Romancing the Shadow" in Playing in the Dark, she writes to those tiresome Africans on their Africanism as follows:

Africanism is the vehicle by which the American self knows itself as not enslaved, but free; not repulsive, but desirable; not helpless, but licensed and powerful; not history-less, but historical, not damned, but innocent; not a blind accident of evolution, but a progressive fulfilment of destiny (52).

Thus, she wants her readers, on the whole - black, white, yellow, brown and red irrespective of their gender - to get something good from her works that they may not have seen directly by the naked eye and naked mind. Morrison may use the white way of telling the blacks' experiences to give a meaning to their life. As Michael Ackward writes in "Roadblocks and Relatives: Critical Revision in Toni Morrison's The Bluest Eye": "Morrison returns to an earlier practice of the white voice introducing the black text - to demonstrate her refusal to allow white standards to arbitrate the success or failure of the black experience" (59). And Morrison shows that the binary oppositions of how a person should not merely live but how to live in the short span of earthly life by using and introducing the negative side of the world, life, and soul. In fact, that is the quality of any good writer.

It is not only the body that survives, but also the soul. To live in the world, human beings do need some kind of energy that may come either within her/him or it may come from an external entity. Whereas the internal force itself needs some kind of charge that might have been imbibed as an inborn quality or might have been received through experience. These instincts come to her/him from undergoing certain personal experiences, watching others' experiences, and through one's wisdom. 
Some are born courageous, and some become courageous. This particular characteristic can be extended to many other characteristics. But to have any experience, human beings need society which is a forceful factor that gives her/him the experiences of the world. Human beings definitely need this connection with society directly or indirectly, whether she/he likes it or not. When a human being has a cordial relationship within herself/himself and with other human beings, she/he would like to live longer to do something good both to herself/himself and to the society at large to which she/he belongs.

Bio-centricity and Necro-centricity are terms that do not have their literary meanings as life and death alone or the involvement of any human being with life and death with another human being or society that she/he belongs to. These terms rather have extended meanings that need socio-cultural terminology. This socio-cultural terminology can be explained through certain experiences of human beings that she/he undergoes within herself /himself or with the external world.

Bio-centricity connects with life, life affirming, life-affording, passion, and positive attitudes towards her/his "being” and other lives. Likewise, Necro-centricity links with nonlife, life-denying, death-dealing, refinement, and negative attitudes towards her/his "being" and other lives. Hence, every activity of each human has the capacity of inflating into either bio or necro centricity that would either help or reject her/him and other people.

Martin Buber's terminologies being and I-Thou relationship connect with biocentricity on the one hand and having and I-It relationship connect with necro-centricity on the other. Those terms I-Thou and I-It are inter-subjectivity and agent-instrument relationships respectively.

Likewise Julia Kristeva uses the terms semic/semiotic and symbolic. Julia Kristeva uses these terms with gender and language, but the terms are used here for bio-necro centricities. According to Julia Kristeva semic/semiotic has positive attitudes and has more 
power in language than in the symbolic that has negative attitudes and less power in language usage. Likewise these two terms can be applied to the human beings and the society that she/he lives in. Peter Barry quotes Julia Kristeva in Beginning Theory as follows:

'The System and the Speaking Subject' the symbolic aspect is associated with authority, order, fathers, repression and control ... This symbolic facist of language maintains the fiction that the self is fixed and unified ... By contrast, the semiotic aspect of discourse is characterised not by logic and order, but by 'displacement, slippage, condensation', which suggests, again, a much looser, more randomised way of making connections, one which increases the available range of possibilities (128 - 129).

Accordingly, bio-centricity and necro-centricity can be linked with semic/semiotic and symbolic respectively.

Toni Morrison drives people to possess positive attitudes towards their own life and to the others' lives, and to have pleasant and meaningful life. She wants the human beings to have a cordial and genteel relationship, first with herself/himself, and then with the external world that she/he lives in. If a woman/man possesses this positive tendency towards life, she/he becomes a bio-centric, and if she/he fails to be so, she/he becomes a necro-centric. This urges Morrison to have her characters either bio-centric or necro-centric in all her novels. The character may be a black or a white or a male or a female, it falls under any one of these two categories.

There are Pilates, Amy Denvers, Paul Ds, and Eva Peaces as bio-centric on the one hand and many Macon Dead - II, Soaphead Churchs, Paulines, Colonel Wordsworth Grays, and Margaret Lenores on the other who are necro-centric. Either they have positive, lifeaffirming and life-giving attitudes or negative, death-dealing, and life-denying attitudes both to themselves and to other characters. 
Sandi Russell writes in "It's Ok to Say Ok":

To be one with this life, to know it and embrace it and draw strength from it: that's what Toni Morrison affirms wholeheartedly. After the many years of suffering and endurance, she argues, blacks can now grasp life and make it their own (53).

Genevieve Fabre in "Genealogical Archeology or the Quest for Legacy in Toni

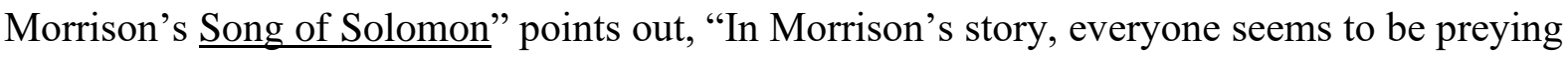
upon others, each character is both a predator and a potential prey" (111). This predator and the potential prey can be used both positively and negatively according to the situation the characters act upon. But when we closely analyze Morrison's characters, we can find that embracing and strengthening life and the self from the sufferings, both the predator and the potential prey are not confined to any race or to any gender.

Life-Affirming versus Life-Denying

The black female character Eva Peace in Sula and Pilate Dead in Song of Solomon underwent many tragic and pathetic incidents in their lives. Eva Peace's husband BoyBoy ran away, leaving three small children with her. She lost one of her legs (others said that Eva Peace lost her leg in order to obtain insurance, but readers still do not know how and when her leg was amputated and how she came with a big sum of money to build a big house) and brought up her children. She did not regret her pains to bring up the children and the grandchild with only the existing one leg. She not only underwent physical suffering but also faced abuses from her own society. But she lived even after her granddaughter Sula's death. Pilate on the other hand lost her mother at the time of her birth, born without a navel, lost her father, and finally confronted with her brother Macon Dead - II and left him and led her life alone as burger. Whatever society she lived in, it kept her aloof after seeing her belly without a navel and the society treated her as an evil-woman. As in the case of Eva Peace, Pilate too 
brought up her daughter and granddaughter with her meager earning and big courage. She protected not only herself but also her daughter and granddaughter without losing her root African tradition. Anne Adams adds strength to the above writing in "Straining to Make Out the Words to the 'Lied': The German Reception of Toni Morrison":

... Eva Peace and Pilate Dead, who both fill the strong-grandmothers stereotype, actually give some new dimensions to the stereotype: they don't manifest the proverbial clichéd love for children, and, with their respective deformities - Eva's missing leg, Pilate's missing navel - they both have a mythical aura about them (199).

It is difficult to deny that the black women in the US are doubly oppressed. That is, racially the blacks are oppressed first by the whites, if not politically but socially. Secondly, the black culture in general, a patriarchal culture, and that society does not treat women as equal with men. Even women admit it. Ania Loomba in Colonialism / Postcolonialism mentions: "Historically ... black women suffer from both racial and gendered forms of oppression simultaneously" (163).

Eva Peace on the one hand was a deserted wife; she had a widowed daughter Hannah Peace and a "free-moving" granddaughter Sula Peace, in the novel $\underline{\text { Sula. }}$ Pilate on the other hand did not have a husband and she had a "free-moving" daughter Reba who too did not have a husband as her mother. Pilate loaded herself with the weight of looking after her granddaughter Hagar who had been deserted by her lover Milkman in Song of Solomon. Readers would definitely have insight of the sufferings of these two women, Eva Peace and Pilate Dead! Further their lives in the black society were too crucial to describe! But they lived and let others live. They affirmed not only their own lives, but also affirmed others living both inside and outside members of their family. Though they had their own rigidity 
towards culture and other such matters, they were lovable. They had enough courage to stand alone in their respective societies, fought for their rights, and lived for themselves and others.

Consider the black male characters Macon Dead - I (Jake) in Song of Solomon and Paul D in Beloved. Macon Dead - I had lost his original name, and with his Indian wife Sing he had established himself with a small piece of land. Later he lost his wife and he alone brought up his children, finally lost his life. Had he wanted, he could have been another daily wage-earner as an ex-slave. But he was determined to live; not just a living, but a happy living. Reverend Cooper and Circe in Song of Solomon told milkman that Macon Dead - I led a happy life and made others happy. Whereas Paul D in Beloved, another ex-slave suffered a lot and lived with a trauma of his past slave life. He came back to 124 , Bluestone Road and told Sethe that he came back to take care of her from her ghost-daughter Beloved as: "'Look ... Denver be here in the day. I be here in the night. I'm a take care of you, you hear? Starting now" ( saying: "'Sethe ... me and you, we got more yesterday than anybody. We need some kind of tomorrow" (Beloved 273). This is also reiterated by Barbara Schapiro in "The Bounds of Love and the Boundaries of Self in Toni Morrison's Beloved" in Contemporary Literature:

Paul D is the one character in the novel who has the power to resist and disrupt the destructive, narcissistic mother-child dyad ... His power lies precisely in his maternal, nurturing quality; he is that "other" with the power to recognize and affirm the inner or essential self ... The women see him and not only weep; they also want to confess their deepest secrets, to expose all the pain and rage bound up with their true selves $(307-308)$.

Consider the Garners in Beloved who were whites and owners of the slaves Sethe, Paul D, Sixo, Halle, and others in the Sweet Home. Lillian Garner never treated his slaves as other white masters did during that evil period. Mr Garner was considerate towards his black 
slaves. He allowed his slaves to read and he paid wages to them. Besides he never got the "happiness" of giving his slaves to his friends and relatives for sex nor did he rent them out for sex in order to "breed". Baby Suggs was a former female slave to the Garners, told about the Garners thus,

The Garners ... ran a special kind of slavery, treating them like paid labor, listening to what they said, teaching what they wanted to know. And he didn't stud his boys. Never brought them to her cabin with directions to 'lay down with her,' like they did in Carolina, or rented their sex out on other farms ... In fact, his order for them not to leave Sweet Home, except his company, was not so much because of the law, but the danger of men-bred slaves on the loose (Beloved $140-141)$

Till Mr Garner was alive no slave tried to run away from the Sweet Home. When Sethe arrived at the Sweet Home, the male slaves (five in all) did not touch Sethe, and they waited for a year till Sethe selected her man. The text illustrates Garners treatment as follows: "A year of yearning, when rape seemed the solitary gift of life. The restraint they exercised was possible only because they were Sweet Home men - the ones Mr Garner bragged about" (Beloved 10). This was possible because of the behaviour of the Garners towards their slaves. When Halle, the male slave of the Garners wanted to purchase his mother's (Baby Suggs's) freedom, Mr Garner allowed it, later arranged a house (124, Bluestone Road) with the help of the Bodwins, and arranged some kind of livelihood for Baby Suggs. Also, Mrs Garner allowed Sethe to marry Halle, and she allowed her to sew a dress for their wedding. To the surprise of Sethe, Mrs Garner gifted a pair of earrings to Sethe as a wedding present which was totally unusual and not at all the practice of any white masters (mistress) towards their slaves during that period. 
Another white female character Amy Denver in Beloved helped Sethe to a greater extent at the time Sethe delivered her baby in the jungle while Sethe was a runaway slave from the Sweet Home. The help extended by Amy Denver made Sethe name her last daughter Denver, with gratitude. It is noteworthy here that on her way to Boston, Amy Denver met Sethe in the jungle and spent her time with the black runaway to deliver her baby. Also, Amy tied Sethe's wounded bleeding feet with leaves and pieces of shawl. When Sethe delivered her baby, Amy washed and wrapped the infant and tied it to Sethe's chest for the security of the infant. Amy Denver was a Good Samaritan who helped Sethe by all means.

Sixo, one of the male slaves in the Sweet Home afforded life to others and affirmed his life with the "thirty-mile-woman" and had a practice of walking thirty miles up and down to meet the woman without the knowledge of his master to get boosted for the following week. When he was caught by his new white master Schoolteacher, he sang till his death though Schoolteacher tortured Sixo very badly. The following dialogue between Sixo and Schoolteacher reveals how Sixo affirmed his life and his quality of life-affirming when he was got caught by his slave master while stealing a pig:

'You telling me you didn't steal it, and I'm looking right at you?'

'No, sir. I didn't steal it'

'And you telling me that's not stealing?'

'No, sir. It ain't.'

'What is it then?'

'Improve your property, sir.'

'What?' 
'Sixo plant rye to give you high price a better chance. Sixo take and feed the soil, give you more crop. Sixo take and feed Sixo give you more work' (Beloved 190).

Sixo's above reply shows how positive/optimistic he was towards his actions, even though he was involved in stealing. He was dead at the end, but dominated the hearts of everyone in the Sweet Home that made the readers place him though he appeared in a tiny role in the whole novel.

The fugitive black male Son in Tar Baby affirmed life to Jadine. He killed his wife Cheyenne when he saw her sleeping with a teen-aged boy. But, later he showed Jadine the correct path to live. Yet she did not accept it. When he came to know that the owner of the house, L'Arab de la Croix, Valerian Street, fired the yardman Gideon and the washerwoman Thérèse, since they stole apples, Son fought with Valerian that his dismissing them from their work was wrong. When the Streets, the black servants Sydney and Ondine, and Jadine called Yardman and Mary without using their proper names, it was Son who told those people to call them by their names Gideon and Thérèse respectively through which he affirmed life to those two poor black people. These incidents took place during his asylum at the house L'Arab de la Croix. Though Son was an American he had the nature loving African roots. His anger was on the Americans who did not go along with nature and whose mind had been diverted towards "waste" as follows:

"... the sole lesson of their world: how to make waste, how to make machines that made more waste, how to make wasteful products, how to talk waste, how to study waste, how to design waste, how to cure people who were sickened by waste so they could be well enough to endure it, how to mobilize waste, legalize waste and how to despise the culture that lived in cloth houses and shit on the ground far away from where they ate. And it would drown them 
one day, they would all sink into their own waste and the waste they had made of the world ..." (Tar Baby $204-205)$.

He warned them like an ecologist what would happen to people and the world, if they continued to go against nature. Though it may be seen that Son's ideas of happy life confined to the Black Codes (or rather Black Values of the black African-Americans), it was he who finally kindled Jadine's idea of living. Not only Son moved the heart of Jadine, but also he became an example to the white male character Valerian who gave asylum to Son. When Jadine wanted to live in New York, Son told her: "WWe are living in other people's space. This is not our crib. Let's go someplace else"' (Tar Baby 269). Son helped the lonely black girl Nommo when she had been scolded and ill-treated by a group of men, and gave her his apartment to sleep that night to give her protection. Thus, Son is a life-affirming character, plays a leading role in affirming life to others irrespective of race and class than his own life.

The above mentioned characters affirmed life to other characters as they affirmed their own lives. But on the other hand, there are many characters with life-denying attitudes. There are many Guitars, Paulines, Soaphead Churches, and Violets who denied life and they did not have any grip in their lives as well as they had a disinclination to let others live.

One of the prominent activists of the Seven Days was Guitar in Song of Solomon who gets into the first place in the race towards necro-centricity though other life-denying characters get minimal differences in the competition. Guitar first revenged the white people to the killing of the blacks anywhere in the US. The aim of the Seven Days was to equalize the murder of the black people anywhere in the US by murdering an equal number of whites in the same manner as the blacks had been killed. Guitar was not only a prominent activist of the Seven Days, but also he propagated the activities of the Seven Days to Milkman, and later he made the other black boy Empire State to become a member of the group. Readers may think at the early stage that Guitar was a mentor to Milkman, but later Guitar's lust for money 
and his selfishness were exhibited to everyone. At the height of his selfishness and lust for money, he killed Pilate - aiming at Milkman but missed the aim. Guitar did not have any positive attitudes towards his life nor did he apply the same on others. Thus he did not dominate anyone.

Pauline Breedlove was Pecola's mother in The Bluest Eye. She had her own ways of living and she fantasized a romantic life. Her romantic ideas of beauty and life had been passed on to her daughter Pecola; and that led to Pecola's ruin. The narrator says how the romantic love and romantic ideas ruined her as follows:

Along with the idea of romantic love, she was introduced to another - physical beauty. Probably the most destructive ideas in the history of human thought. Both originated in envy, beauty with virtue, she stripped her mind, bound it, and collected self-contempt by the heap. She forgot lust and simple caring for. She regarded love as possessive mating, and romantic as the goal of the spirit ... She was never able, after her education in the movies, to look at a face and not assign it some category in the scale of absolute beauty, and the scale was one she absorbed in full from the silver screen (The Bluest Eye 95)

It is clear that romantic ideas do not help to live a practical and real life and that it would lead to the destruction of life as in the case of Pauline and Pecola. Alvin W. Gouldner writes: “'Romanticism' thus emphatically subverts and rejects the rights of the family system to control the relations between the sexes and most particularly, the subordinate role of the women" (103). Thus, this was the only reason for the dissociation of Pauline's family - her husband Cholly Breedlove raped his own daughter and later ran away and died; her eldest son Sammy Breedlove became a regular runaway child; Pecola was raped by her father and was abused by Soaphead Church, and Pecola became mad - that led Pauline to live "in that little brown house ... on the edge of town" (The Bluest Eye 162). It is clear that from the very 
childhood of Pauline, she lived her life in her own way and it lasted till the end of the novel, and her life led her to life-denying quality.

The black female character Violet in $\underline{\text { Jazz }}$ was in her fifties, loved only her parrot and in-door plants, and slept with a big doll in the nights. She was the root cause of her husband Joe Trace's ruin. She never talked to her husband, cooked foods that he did not like at all, and served the food mechanically. The text shows that the couple Violet and Joe came from Virginia to New York to live. Violet might have had a pathetic life in her childhood, but she had a strong, life-affirming grandmother, True Belle and a good, hard-working, and lovable husband Joe in the beginning. Though Violet extended her hands friendly to the angry old woman whose niece had been murdered by Violet's husband, Violet's actions like disfiguring Dorcas's dead body and her doubtful and unfriendly family life make us decide that she was a life-denying character.

Colonel Wordsworth Gray in Jazz was a rich plantation owner who wanted to keep his social reputation which led him to chase away his only child Vera Louis Wordsworth Gray when he came to know that his daughter had an affair with one of his black slaves and had been impregnated by him. Colonel Wordsworth Gray "visualizes the seven mulatto children on his land" that makes him slap his daughter (and the slap has been acknowledged by his wife). Had his social reputation failed him to keep his daughter, he could have sent her to some other place under his own administration. Instead, he did not even speak with his daughter, kept only a note with the money. Thus, it is clear that Colonel Wordsworth Gray and his wife did not affirm life to their only child and to the foetus, and they are life-denying characters.

Life-Affording versus Death-Dealing

It is noteworthy to differentiate between life-affirming and life-affording. Many characters of Morrison charge other characters to live in the world with human predicaments. 
The life-affirming characters may tell the proper way to live by their words or by their deeds. At the same time, these life-affirming characters live with their personal, physical, and mental sufferings, and they become examples to others. But those life-affording characters have enough stamina to live, first for themselves, and then for others. Martin Buber's term I-Thou relationship can be applied to those life-affording characters.

Likewise, life-denying does not mean death, but it has a figurative meaning that those who do not have any grip in life and make others also live the same. The term death-dealing attributes not only trauma caused to herself/himself but also to mental and physical destruction to others.

True Belle and Alice Manfred in Jazz were the two old black female characters. True Belle was Violet's grandmother who had been with her white mistress for twenty-two years when her white mistress had forcibly been sent away from her home by her father. True Belle accompanied her mistress and brought up her mistress' mulatto child Golden Gray for eighteen years. When True Belle came to know that her daughter Rose Dear and grandchildren were left alone in Rome, Vesper County, Virginia, she immediately came to their rescue and saved them. True Belle's daughter Rose Dear committed suicide immediately after the arrival of True Belle. She brought up her granddaughters Violet and her two sisters since Violet's father did not stay with his family and only occasionally visited his family. True Belle not only gave life to her own blood - her granddaughters, but also brought up the mulatto child Golden Gray for eighteen years with care and love. Her care and love were echoed in many places by Golden Gray himself when he visited his father Henry Lestory. True Belle told Golden Gray about his father and the way to find him. Not only she afforded life to human beings, but also True Belle afforded life to animals. She reared a cat and gave maximum comfort to it. The poor servant maid made a pillow for its comforts and she cared for it more than a cat. She named it King. According to Golden Gray 
in the text: "She had been given the name of a powerful male dog, but she was a cat without personality, which was why True Belle liked her and wanted her close by” (Jazz 152). True Belle was a courageous woman who wanted others to be like her and that made her send her granddaughters to work in the cotton fields of Palestine, Virginia at their young age. Also the naming of her impersonal cat as King is evidence that she wanted others to be courageous too.

Alice Manfred's up bringing was traditional. She married Louis Manfred who was unfaithful to her and died later. Alice's sister and brother-in-law were the victims of the East St Louis riots that made her bring up her niece Dorcas Manfred with the same care that she got from her parents. Alice wanted her niece Dorcas too to be brought up like her, but pathetically Dorcas did not accept her niece's view which led her to meet with an untimely death. Does Alice come under the category of life-affording since she brought up her orphaned niece Dorcas, with religious rigours? No! Alice exhibited her love towards her enemy, Violet (or suppose so), who tried to damage Dorcas' dead body in the church during the funeral service. Though Alice did not want to meet Violet at first and called her "Violent" later met her. Alice was a true Christian who forgave her enemy as said by the Lord: "Thou shalt love thy neighbour as thyself. There is none other commandment greater than this" (Mark 12: 31). Anyone who loves and cares for the enemy should be praised and so was to Alice Manfred. It was Alice who again gave a new lease to Violet's life.

Alice was not only a soft and a lovable person, but also a courageous woman with a lot of stamina to survive with the white people in New York City. In New York, Alice experienced many obstacles and the narrator describes these as follows: ... whiteman leaned out of motor cars with folded dollar bills peeping from their palms. It was where salesmen touch her and only her as though she were part of the goods they had condescended to sell her ... ( Jazz 54). 
Alice hated then evolving jazz music. She wanted the black women to be courageous with physical and mental stamina, for, she was brought up the "black traditional" way. Alice said: "Black women were armed; black women were dangerous and the less money they had the deadlier the weapon they chose" ( $\underline{\text { Jazz }} 77)$. Her belief in God is expressed in the following passage thus,

Those who found protection in church and the judging, angry God whose wrath in their behalf was too terrible to bear contemplation. He was not just on His way, coming, coming to right the wrongs done to them, He was here. Already ( $\underline{\text { Jazz } 77) . ~}$

The unsafe, defenseless, and subdued nature of the doubly oppressed black womanliness made her avoid approaching the police for her niece's murder. At the height of her frustration Alice said: “Didn't everything on God's earth have or acquire defense? Speed, some poison in the leaf, the tongue, the tail? A mask, flight, number in the millions

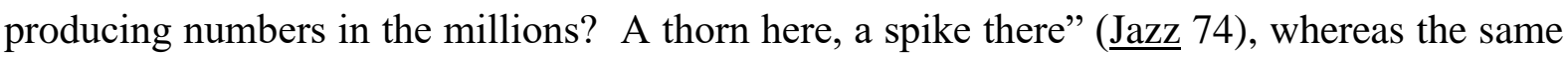
Alice's inability to avenge her husband's unfaithfulness made her do childish acts as “... she planned sugar in his motor, scissors to his tie, burned suits, slashed shoes, ripped socks. Vicious, childish acts of violence to inconvenience him, remind him" (Jazz 86). These were the factors that made Alice Manfred a courageous woman who had a lot of life-affording qualities. True Belle and Alice Manfred dominate the minds of other characters and the readers.

The black male characters Henry Lestory and Joe Trace in Jazz were life-affording to others. Henry Lestory was a black slave to Colonel Wordsworth Gray. His white mistress Vera Louis was impregnated by him and later she left him. Henry Lestroy lived in the woods and surfaced after the search of his mulatto son Golden Gray. Henry Lestory extended his love not only towards his son when he saw him for the first time, but also to the just seen 
unknown woman, and christened her as Wild and this act made him a father like figure to her. It is natural for any human being to love his/her offspring. But, it is always strange to love a savage who does not even know any language at all where her gestures being the only language. But Henry Lestory did this strange thing to the savage woman and helped her to deliver her child even after her violent act during the childbirth; cared for her, and even after everybody left him, he communicated with her (may be due to his fatherly affection towards her). When Wild touched him after thirteen years, he did not get frightened of her though everyone in the place was afraid of her. But Henry Lestory felt sad about her present pathetic condition - being in the woods away from any human touch and attention. Henry Lestory's life-affording qualities were shown primarily when he helped Wild to deliver her baby. He found that the newborn baby needed immediate nursing, and he sent his helping boy, Honor, to bring some women to nurse the infant without further delay. Further, when he told Joe about Wild, Henry Lestory empathized with Joe's longing for mother's love and introduced the waif to Joe, irrespective of the observations of the society about Wild. Henry Lestory told about the woman as follows: "She got reasons. Even is she crazy. Crazy people got reasons" (Jazz 175). This shows the following main points that firstly Henry Lestory became a father figure to Joe too since he introduced Joe's mother; secondly Henry Lestory cared for the so called "crazy" people too and empathized with them; and thirdly, though he missed his wife (or lover) Miss Vera Louis, he lived with her thoughts even after eighteen years. He told Golden Gray to come with Miss Vera Louis's "green dress", and kept it with him till the end of the novel. Finally, when everyone in Vesper County was forced to evacuate from their place, he was the only person to stay in Vesper County, and that shows his love and gratitude towards the life-affording soil.

Violet, the wife of Joe Trace in $\underline{\mathrm{Jazz}}$, neither loved her husband nor cared for him in any way. He did not have any connection with his mother. He self-christened himself like 
Stamp Paid in Beloved. According to him, he was born-again seven times, loved an eighteen-year-old girl, and later he became a murderer. His unhappy life from his childhood to his fifties did not affect his life-affording qualities. He loved himself first and there after extended it towards others. Alice Manfred's observations about Joe were thus,

A nice, neighborly, everybody-knows-him man. The kind you let in your house because he was not dangerous, because you had seen him with children ... Felt not only safe but kindly in his company because he was the sort women ran to when they thought they were being followed, or watched or needed someone to have the extra key just in case you locked yourself out ... Who warned young girls away from hooch joints and the men who lingered there. Women tease him because they trusted him. He was one of those men who marched down Fifth Avenue ... He knew wrong wasn’t right ... ( $\underline{\text { Jazz }} 74$ $-73)$.

Though he did not know his wife Violet's abnormal behaviour in public, he continued to love her, cared for her, and then confronted her. His wife's silence annoyed and caused inconvenience and depression. The narrator says: "He is married to a woman who speaks mainly to her birds" (Jazz 24). Hence, it is natural for a husband to go for another woman if his wife maintains silence and inconveniences him. But until he found out that she slept with a doll, he extended his life-affording nature to her. Only after that he fell in love with Dorcas. He said that Violet was like a piece of furniture; "you need it but use it whenever you want to" (Jazz 123), but it was all her abnormal behaviour that made him shift away from her. He liked peppermint as a kid even in his fifties. And he thought that everyone did the same which made him imagine Dorcas with candy. That gave a sort of life to Dorcas who thought that she had not been loved by anyone, and her activities formulated everyone think that she was a pessimist. He told Dorcas's friend Felice, after he murdered Dorcas, that no one loved 
Dorcas before him, and added that he was the only one who noticed the soft side of Dorcas, since he was the only one who noticed Dorcas's tears and it was, therefore, evident that Dorcas cried in front of Joe only, because Felice told Joe that Dorcas never cried in her life. That is, Dorcas got comfort and consolation from Joe that made her cry. That simple above act of Dorcas shows that Joe gave her life and his life-affording nature burst out there. This same quality can also be seen in Paul D in the novel Beloved that women wept before him. Though Alice Manfred is a bio-centric character to others, she did not play the positive part to Dorcas. Since Dorcas was a teen-aged girl, she might have felt imprisoned in the hands of Alice's rigidity. But it was Joe who showed Dorcas the positive part of love and care that were magnificent and incomparable. Joe Trace was humourous and this sense made him live leaving all his pathos behind him as the text shows, “... you were the reason Adam ate the apple and its core. That when he left Eden, he left a rich man. Not only did he have Eve, but he had the taste of the first apple in the world in his mouth for the rest of his life (Jazz 133). His optimism made him a life-affording person. Though he murderd his teen-aged lover Dorcas, he did it accidentally and the death of Dorcas made him feel sorry, and that made him cry for more than three months which he disclosed only to Felice. Thus Henry Lestory and Joe Trace become dominant to other characters.

The MacTeers in The Bluest Eye were the foremost life-affording parents to their daughters Claudia and Frieda and to Pecola Breedlove as well. Though Mrs MacTeer's harsh attitudes and Mr MacTeer's spying nature towards their daughters made their daughters unhappy, they gave courage to Claudia - her mind - and that made Claudia a strong woman later in her life. When Pecola was sent outdoors, Mrs MacTeer brought Pecola into her house (though it was the order of the society that they lived in, Mrs MacTeer did everything that she should do to her own daughters and she exercised the same strictness with Pecola as with her own daughters such as at the time of drinking milk) and comforted Pecola. When Pecola 
experienced her menarche, Mrs MacTeer comforted Pecola and later washed Pecola's clothes. Mrs MacTeer was a perfect mother who cared for her daughters. When Claudia puked in the bed, Mrs MacTeer scolded Claudia but treated her well later, and this tendency had been extended when Claudia caught a cold. Later when their roomer Henry Washington abused Frieda, it was Mrs MacTeer beat Henry up with a broom and got angry when Henry sang a song (since according to Mrs MacTeer, Henry abused the Lord's name). She did not allow her daughters to visit the three prostitutes China, Poland, and Miss Marie. According to Mrs MacTeer, Maginot Line [Miss Marie] was the one who "wouldn't let eat out of one of her plates" (The Bluest Eye 60). Likewise, Mr MacTeer watched his family and the house day and night, and instructed his children how to do things properly. At night hours while going from the bathroom to his bedroom, he stopped at his daughters' room to check whether they were asleep and only after confirming that they were asleep, he moved to his duties. According to Claudia, Mr MacTeer was a "Vulcan guarding the flames" (The Bluest Eye 47). When Henry Washington picked at Frieda, Mr MacTeer came to know it through his wife and he threw a tricycle on him first and then shot at Henry with a gun. Together the MacTeers took care of their daughters and they were responsible for the daughters' good breeding and courageous nature. For instance, the courage and good breeding made Claudia oppose the white-adopting culture. Claudia said about the caring of her mother as: "Mama said we was never to cross the tracks by ourselves" (The Bluest Eye 77), this quality was missing in the Breedloves' that led to the ruin of their daughter Pecola and often their runaway son, Sammy. On the whole, the MacTeers exhibited full of life-affording qualities not only with their daughters but also with others.

Aunt Jimmy was a black, old female character in The Bluest Eye. She had been a slave and suffered a lot while in slavery. The following passage is a typical example of the sufferings of the black women: 
Everybody in the world was in a position to give them orders. White women said, 'Do this.' White children said, 'Give me that.' White men said, 'Come here.' Black men said, 'Lay down.' The only people they need not take orders from were the black children and each other ... They ran the houses of white people, and knew it. When white men beat their men, they cleaned up the blood and went home to receive abuse from the victim. They beat their children with one hand and stole for them with the other. The hand that felled trees also cut umbilical cords... (The Bluest Eye 108).

With all those sufferings, Aunt Jimmy found the four-day old Cholly when his mother wrapped him in a paper and kept the infant on the railroad. Aunt Jimmy took him, christened him, and brought him up, and finally she never allowed Cholly's mother near Cholly since Aunt Jimmy thought that Cholly's insane mother might harm Cholly. The text highlights her love as; "Aunt Jimmy raised Cholly herself, but took delight sometimes in telling him of how she had saved him ... Cholly was grateful for having been saved" (The Bluest Eye 103). Then Aunt Jimmy told Cholly about his father and the money that she saved which finally helped Cholly to see and to realize his father after Aunt Jimmy's death. By christening him, she became Cholly's father like figure as well. The above examples show that Aunt Jimmy is a life-affording character in The Bluest Eye, and she became a dominating character.

One of the three prostitutes in The Bluest Eye who lived in the apartment above the Breedloves was Miss Marie who told about the unfaithful wives thus, "sugar-coated whores" (The Bluest Eye 48) and she respected "good Christian colored women" (The Bluest Eye 48). Though by profession she was nefarious, she was one of the very few friends who comforted and loved Pecola. When Claudia and Frieda searched Pecola for whiskey after Frieda was abused by Henry, Miss Marie showed the way to find Pecola, and she was concerned about the two little girls and asked whether they were able to reach Pecola safely. Though Mrs 
MacTeer called Miss Marie "Maginot Line" and Mrs MacTeer did not allow her daughters to visit the prostitutes' apartment, Miss Marie loved the girls and she did not show any hatred towards the girls. She told Pecola old stories about her and other cooked-up stories; and her stories relieved most of Pecola's pains. According to her profession, she was a life-denying character, yet, the manners and the concerns she exhibited towards others make her a lifeaffording character.

The two sisters Claudia and Frieda were small black girls in The Bluest Eye. From the beginning they were the only sincere friends to Pecola. Maureen Peal was a rich black girl who was of the same age of Claudia, Frieda, and Pecola. She befriended Pecola and tried to compare her riches and beauty with the black, ugly, girl Pecola Breedlove. But, Claudia and Frieda who had been carefully parented, did good to Pecola. At the time of Pecola's arrival in their home when she became outdoors, the two sisters showed concern in the welfare of Pecola. They gave their milk to Pecola in the cup that Pecola liked the most (the cup that has Shirley Temples' figure etched). Later they comforted Pecola whenever Pecola became frustrated. Though the parents of the sisters were strict, the two sisters went beyond their limit to help their poor ugly friend. When they came to know that Pecola was raped by her father and was pregnant, these two little sisters tried their best to save her foetus. The narrator Claudia tells how she and her sister were concerned about Pecola and the foetus as follows:

I thought about the baby that everybody wanted dead, and saw it very clearly ... I felt a need for someone to want the black baby to live - just to counteract the universal love of white baby dolls, Shirley Temples, and Maureen Peals. And Frieda must have felt that Pecola was not married ... we did not dwell on the fact that the baby's father was Pecola's father too; the process of having a baby by any male was incomprehensible to us - at least she knew her father. 
We thought only of this overwhelming hatred for the unborn baby ... Nobody paid us any attention, so we paid very good attention to ourselves. Our limitations were not known to us - not then. Our only handicap was our size; people gave us orders because they were bigger and stronger. So it was with confidence, strengthened by pity and pride, that we decide to change the course of events and alter a human life (The Bluest Eye 149 - 150).

Finally the girls planned to sell marigold seeds door to door to raise money to protect the foetus. But they planned earlier to sell the seeds to buy a bicycle, and now they sacrificed the idea for a noble purpose. Consider the sacrifice of the two little girls. They were not only concerned about human beings, but also extended their love to non-humans like birds that they tried to save their lives which could be known through their conversation. It is noteworthy to mention that they comforted each other as well. When Claudia caught a cold or fever or even puked, Frieda comforted Claudia, and when Frieda was abused by Henry Washington, Claudia comforted Frieda (though their knowledge of the word "ruined", and drinking whiskey in order to avoid becoming fat etc. were their innocent behaviour due to their age since Claudia was nine and Frieda was ten at that time). Thus, Claudia MacTeer and her sister Frieda MacTeer had full of life-affording qualities, and that life-affordability might have come through the breeding of their life-affording parents. Claudia's final confession on Pecola was clear enough that Claudia was true to herself and her confession was universal to all the human kind. She angrily told the people who used the ugliness of Pecola as follows:

"All of our waste which we dumped on her and which she absorbed. And all of our beauty, which was hers first and which she gave to us. All of us - all who knew her - felt so wholesome after we cleaned ourselves on her. We are so beautiful when we stood astride her ugliness. Her simplicity decorated us, 
her guilt sanctified us, her pain made us glow with health, her awkwardness made us think we had a sense of humor. Her inarticulateness made us believe we were eloquent. Her poverty kept us generous" (The Bluest Eye $162-163$ ). And later Claudia confessed that Pecola was a scapegoat to her society and on the whole to the black community which is seeking "whiteness; in the black society. Hence, Claudia and Frieda dominate everyone with their love and care to all the life in the world.

Cecile was a black female character in the novel Sula. She was Nel's greatgrandmother who took care of her granddaughter Helene Sabath Wright whose mother was a Creole prostitute. Cecile was a strict religious lady who did not want her granddaughter Helene Sabath to live with Cecile's daughter and Helene's mother. Hence Cecile brought up her granddaughter in the same strict religious manner and got Helene to marry her nephew, Wiley Wright. Helene also grew under the shadow of her grandmother and Helene wanted to bring up her daughter, Nel in the same manner. She did not want her daughter to be shadowed by her prostitute mother. When Helene and Nel went to attend Cecile's funeral, Helene did not pave the way for her mother to communicate with her daughter, though the grandmother and the granddaughter met for the first time. Thus, the two black female characters Cecile and Helene had life-affording qualities, though they had generational gap.

The old black woman and ex-slave, Baby Suggs in Beloved had been a life-affording character throughout her life. When she was a slave under the Garners at the Sweet Home, she was the only woman slave in that house. When her son Halle bought her freedom, she accepted it because she wanted her son to be happy. She did not allow any violent activities throughout her life, but unfortunately she happened to witness the slaying of her granddaughter by her daughter-in-law, Sethe. Even after that incident Baby Suggs advised Sethe and other blacks who lived near her. She did not like any kind of violence, thus she said always, "'Lay em down, Sethe. Sword and shield. Down. Down. Both of em down. 
Down by the riverside. Sword and shield. Don't study war no more. Lay all that mess down. Sword and shield"” ( preached only love - love themselves first and love others. Her long sermon went as follows that would show the way she told her fellow-blacks to love their own self first:

'Here ... in this here place, we flesh; flesh that weeps, laughs; flesh that dances on bare feet in grass. Love it hard ... They don't love your eyes; they'd just as soon pick em out. No more do they love the skin of your back. Yonder they flay it. And O my people they do not love your hands. Those they only use, tie, bind, chop off and leave empty. Love your hands! Love them. Raise them up and kiss them. Touch others with them, pat them together, stroke them on your face 'cause they don't love that either. You got to love it, you! And no, they ain't in love with your mouth. Yonder, out there, they will see it broken and break it again ... You got to love it. This is flesh I'm talking about here. Flesh that needs to be loved. Feet that need to rest and to dance; backs that need support; shoulders that need arms, strong arms I'm telling you ... they do not love neck unnoosed and straight. So love your neck; put a hand on it, grace it, stroke it and hold it up. And all your inside parts that they'd just as soon slop for hogs, you got to love them. The dark, dark liver - love it, love it, and the beat and beating heart, love that too. More than eyes or feet. More than lungs that have yet to draw free air. More than your life-holding womb and your life-giving private parts, hear me now, love your heart. For this is the prize' (Beloved 88-89).

Immediately after Sethe killed her daughter, Baby Suggs urged Sethe to nurse the infant that was alive in Sethe's hands. Later she took care and brought her two grandsons Howard and Buglar. Baby Suggs wanted to keep the infant granddaughter, Denver too with her when her 
daughter-in-law, Sethe was sent to prison, but Sethe did not accept that proposal. When Sethe returned from prison, Baby Suggs soothed Sethe and gave her a new life in the house 124, Bluestone Road where Baby Suggs lived. Baby Suggs was the dominant character among other characters in Beloved by her universal love and care to everyone.

The other old light skinned woman is Lady Jones in the novel Beloved who taught the poor coloured children. Sethe's last daughter Denver wanted to join "Lady Jones's houseschool" and she accepted Denver as a student and taught Denver for a nickel. When Denver became deaf and stopped going to Lady Jones's school, Lady Jones met Baby Suggs on her way and told her to send Denver to the classes even if Denver did not have money to pay for the tuition. Lady Jones's magnanimity, her thrust for teaching the poor black children, and life-affordability are clearly shown in the following lines of the text: "For a nickel a month, Lady Jones did what white people thought unnecessary if not illegal: crowded her little parlor with the colored children who had time for and interest in book learning" (Beloved 102). And the following lines show how she kept track of her students and how she wanted to teach them, not for money, but as a service to educate the poor black children of her society:

When suddenly she had stopped coming, Lady Jones thought it was the nickel. She approached the ignorant grandmother one day on the road, a woods preacher who mended shoes, to tell her it was all right if the money was owed (Beloved 247).

These two old women characters, Baby Suggs and Lady Jones, in Beloved have life-affording qualities to the depressed poor black souls. They certainly dominate all other characters by their life-affordability.

Then, the Bodwins - a brother and a sister - were whites and strongly disapproved the slave system in Cincinnati in Beloved. Mr Edward Bodwin gave his house; 124, Bluestone Road to Baby Suggs and showed her ways to earn on her own by her already known shoe- 
mending and shoe-making craft and washing, after she freed herself from the Garners (of course, her son Halle bought her freedom). Then, after Sethe was released from jail, $\mathrm{Mr}$ Bodwin helped her to get a job. Later when Sethe was obsessed with Beloved and the house starved of Beloved, Sethe's last child Denver went to the Bodwins to seek a job and $\mathrm{Mr}$ Bodwin promised her a job that gave Denver renewed vigour. He told Denver that he would pick her up at her house to her workplace. Even after Beloved (the ghost girl) and Sethe insulted him, he continued to help Denver. Though the Bodwins are whites, they too have full life-affording qualities.

Stamp Paid is another black male character in Beloved. He helped Sethe when she escaped from the Sweet Home to her mother-in-law Baby Suggs. Immediately after Sethe gave the child birth, Stamp Paid took Sethe to the other side of Ohio River with the one-dayold infant, Denver. While crossing the river he gave his coat to the infant and the mother to protect them from cold, and he safely handed over Sethe and Denver to Baby Suggs. When Stamp Paid met Paul D after eighteen years, he told the story about Sethe. Later when Paul D was tired of the ghost girl Beloved and got out of 124, Bluestone Road, it was Stamp Paid who charged Paul D to return to Sethe to give her life back. Stamp Paid loved his own self and wanted his body and soul to be free from anything. Those made him change his name and self-christened him. The following passage show how that makes him change his name and his helping nature to others and these make Stamp Paid a life-affording character:

... he had misnamed himself and there was yet another debt he owed. Born Joshua, he renamed himself when he handed over his wife to his master's son. Handed her over in the sense that he did not kill anybody, thereby himself, because his wife demanded he stay alive. Otherwise, she reasoned, where and to whom could she return when the boy was through ... Whatever his obligations were, that act paid them off. He thought it would make him 
rambunctious, renegade - a drunkard even, the debtlessness, and in a way it did ... so he extended this debtlessness to other people by helping them pay out and off whatever they owed in misery. Beaten runaways? He ferried them and rendered them paid for; gave them their own bill of sale ... (Beloved 184 $-185)$.

The white male character Valerian Street in Tar Baby was born rich in Philadelphia and sold all his properties and settled in the Caribbean, built a house, and lived with two of his black servants. His wife visited their house to the Caribbean occasionally. Though a white, he spent money on the education of his black servants' niece Jadine, even after her education he continued to help her, gave her equal place in his house, and became a benefactor of Jadine. He did his maximum to bring up Jadine. When Son entered L'Arab de la Croix as a thief (if not to Valerian but to the others in the house), Valerian treated Son as a human and with Valerian's humane qualities Son got a place in the house. He even allowed Son to sit equally with him at the dining table and was given a room in the house to sleep. Valerian gave money to Son to buy dresses and had his haircut. Though others in the house, including Son, thought that Valerian did all those to Son to show his anger against his wife Margaret, it was the basic thing that saved Son from starvation. Even if we argue in favour of Margaret and others in the house that the actions of Valerian were evil, the basic quality of life-affording in his actions are seen throughout the novel.

The two black characters Sydney and Ondine in Tar Baby were husband and wife and the servants to Valerian Street. They played a vital role in the making of their orphaned niece Jadine from her childhood and with their life-affordability, Jadine became a model and stood on her legs. Through their support Jadine established herself in the white society. Further, Ondine loved her white master's son Michael, especially at the time Michael's mother Margaret tortured him by pricking him with pins and burning him with cigarette stubs. 
Ondine soothed Michael, and it was reinforced by Margaret when she met Ondine. Margaret said Ondine: "“you loved my son, didn't you?" and Ondine's sarcastic reply was; "I love anything small that needs it"' (Tar Baby 242). By this it is easy to show that Ondine was the only one to give comfort and soothing to the small Michael who was hurt physically and emotionally by his mother, and this quality of Ondine is clearly life-affording. Ondine dominates the hearts of her mistress, Michael, Jadine, and Valerian Street.

Two other black characters Gideon and Thérèse were the yardman and washerwoman respectively in L'Arab de la Croix. They too played a wider life-affirming role throughout the novel. They were not husband and wife and did not go well with each other. They were not rich enough, but they treated their unexpected guest Son to their maximum, later they helped Son to locate Jadine. When Son tried to locate Jadine in the island, Gideon advised Son: "'A woman, man. Just a woman ... you not going for the address, you going to cause mayhem"” (Tar Baby 303). Thérèse had been a life-affording character throughout her life. She kept food to Son when he hid himself at L'Arab de la Croix at the beginning. It is noteworthy here that Thérèse kept food for Son when she did not know who Son was and she even did not know whether it was a human or an animal or a ghost that hid in the house, but out of humanitarian sense she kept food that saved Son from starving. Finally when Son went out to locate Jadine in the dark, Thérèse helped Son to show the place where L'Arab de la Croix was located. She went alone with Son in the dark in the sea and left Son in the proper place, even after Gideon advised her not to go in the night. Besides her help to Son, she had "magical breasts" that nursed the white children. She was a wet-nurse to the white children. When instant infant milk powder arrived, she felt sad and told Son: "'How can you feed a baby a thing calling itself Enfamil. Sounds like murder and bad reputation. But my breasts go on giving ... I got milk to this day!" (Tar Baby 154). When Thérèse spoke with Son, she inquired about the American mothers who aborted their foetus as follows: "Is it 
true? American women reach into their wombs and kill their babies with their fingernails?'” (Tar Baby $151-152$ ). This shows how she felt sad when she listened that mothers abort their foetus. Her life-affording quality burst out here. Always she remembered the children whom she had nursed and this shows that she did not stop nursing the French children, but she continued to place them as a true mother, and her motherly figure was exposed as follows while she recalled the children whom she nursed: “... she knew ... the two little French girls she took care of one day when the governess ran away, and the hundreds of French babies who used to nurse at her magical breasts ..." (Tar Baby 111-112). Thus, Thérèse becomes a life-affording character who gave life, loved, and cared for many people and dominates most of the characters in Tar Baby.

Contradictory to the above list of life-affording characters, the white character Schoolteacher in Beloved was a death-dealing one. He was a nephew to the Garners and took charge of the Sweet Home after the death of Mr Garner. He is definitely an Anti-Christ figure in the novel. In the first instance, he did not have the quality of a schoolteacher - a misnomer. When he was teaching the white children he took Sethe as an example and told the children the "human and animal characteristics" of her. He tried to deform Sethe from human being to an animal. He allowed his nephew to suckle Sethe's milk and tortured her to the maximum. He lashed her brutally and that created her to have "a chokecherry tree. Trunk, branches, and even leaves" (Beloved 18) on her back. Sethe worked hard for Schoolteacher. The text states about Sethe's job at the Sweet Home for Schoolteacher thus, "... the one he said made fine ink, damn good soup, pressed his collars the way he liked besides having at least ten breeding years left" (Beloved 149). According to Schoolteacher, he wanted the slaves to abide by the rules without any question that he imposed on them, and he said: “... definitions belonged to the definers - not the defined" (Beloved 190). Only after the arrival of Schoolteacher, the six slaves in the Sweet Home thought of running away and 
that made them (especially Sethe) have their bitterest experiences in their lives: Sethe became a life-long prisoner with the thought of her dead (or murdered) daughter and lost her sons, Halle became mad, Sixo had been killed, Paul D became a fugitive and became a wanderer, and the other slaves were unseen. The text gives evidence of the nature of Schoolteacher as follows: “... schoolteacher didn't take advice from Negroes. The information they offered he called backtalk and developed a variety of corrections ... to reeducate them" (Beloved 220). When Sethe killed her daughter, he thought of it in terms of his economic loss, not Sethe as a loving mother. Though he domineered the slaves physically, he did not win over their hearts. He becomes a death-dealing and life-denying character.

The character Beloved in the novel Beloved hits the top-most position among all other death-dealing characters of Toni Morrison's novels. She might be a ghostly reincarnation of Sethe's murdered child, eighteen years ago, as Judith Thurman considers in The New Yorker that the character "calls herself by the name of the dead baby - Beloved - so there isn't much suspense, either about her identity or about her reasons for coming back," or Thomas R. Edwards' conclusion in The New York Review of Books is that the "lovely, historyless young woman who calls herself Beloved ... is unquestionably the dead daughter's spirit in human form," or she may be a human form according to the critic Elizabeth B. House that "Beloved is the one black young girl who escapes from a white slave trader who keeps her for his sexual pleasures" (17-26). Whoever Beloved may be, she was the one who took the life from Sethe, Denver, and Paul D. The moment she entered 124, Bluestone Road, she had been given full attention by Sethe and Denver. From the beginning Beloved was a demanding character from all the three people in 124, Bluestone Road. She got the maximum from Denver, then she seduced Paul D and had sex with him that drove Paul D from the home leaving Sethe and Denver alone with Beloved, and finally Beloved's demands made Sethe become jobless, foodless, and an unhealthy woman. The more Beloved got, the 
less other people in 124 became aware of. She tried to get the best of things in the house which is noted in the text as follows:

Beloved held her head up with the palms of her hands, slept wherever she happened to be, and whined for sweets although she was getting bigger, plumper by the day ... Sethe played all the harder with Beloved, who never got enough of anything: lullabies, new stitches, the bottom of the cake bowl, the top of the milk. If the hen had only two eggs, she got both ... it was Beloved who made demands. Anything she wanted she got, and when Sethe ran out of things to give her, Beloved invented desire (Beloved $239-240)$.

She became a nagging character in the house, but she did it so carefully that everyone paid attention to her. It is evident from the above textual remark that Beloved is a death-dealing woman. The same point is also argued by the critic Deborah Horvitz. Horvitz in Nameless Ghosts: Possession and Dispossion in Beloved goes a step further and says:

Beloved transforms from a lonely, affectionate girl into a possessive, demanding tyrant, and her ruthlessness almost kills Sethe ... Because any attempt to possess another human being is reminiscent of the slave-master relationship ... Just as the disembodied baby ghost Beloved hauntingly possessed Sethe, so the flesh-and-blood adolescent Beloved tries to own and dominate her. Sethe is haunted by the girl's presence as she was by her absence because possession of any kind involving human beings is destructive $(160)$.

It resembles Martin Buber's I-IT relationship which is always destructive. Not that Beloved had a constructive relationship, but Beloved's relationship with Sethe made Sethe lose everything. Finally Sethe had to re-start her life from the beginning with the help of Paul D and her youngest daughter Denver after the disappearance of Beloved. This destructive 
relationship between Beloved and the other three characters in 124 made the community excommunicate them initially, but later made it come closer and help Sethe and Denver. Beloved not only ruined the life of Sethe, but also tried to destroy the future of Denver by making Sethe attempt to kill Mr Bodwin at the time of his arrival at 124 to take Denver to his house as housemaid. And Beloved's disappearance gave life back to 124 Bluestone Road. Thus Beloved is another death-dealing and life-denying character. She never dominates anyone, rather she reduces her status by her acts.

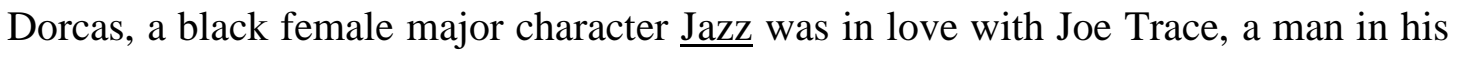
fifties. He killed her finally and that made him suffer throughout his life. A murder cannot be justified, but the cause for the killing may be justified. From the beginning she was a girl who thought of romantic life. When she was a small girl her impudence made her mother slap her and Dorcas left her home and stayed with her friend. Later when her mother had been murdered by the rioters, Dorcas did not think of her dead parents nor did she think about her burning house, instead she thought of her doll which had been burned in the fire that killed her mother. Though she lived with her strict and religious aunt Alice Manfred, she had her own way of living, irrespective of the good advice from her aunt. When she was sixteen, she went to a dance party with her friend without the knowledge of her aunt while her aunt had gone out. It could be argued that since Dorcas was a teen-aged girl it was natural to break the boundaries that the elders created. But, as a teen-aged girl, she had to abide by her guardian, since being an orphan, Dorcas was brought up by her aunt and it was her duty to abide by her aunt's ideals though Dorcas might have thought that the rules were archaic and outdated. Further, she made Joe take her to some particular party and wanted to be in her own fantasy world. Dorcas's friend Felice remarked about Dorcas as follows: "Steal things, or go back to the store and slap the face of a white salesgirl who wouldn't wait on her, or cuss out somebody who had snubbed her. Beats me. Everything was a picture show to her" (Jazz 
202). This is clear enough to show that Dorcas is a death-dealing character who had bad habits like stealing and the like. Any romantic life is destructive of the family system. The

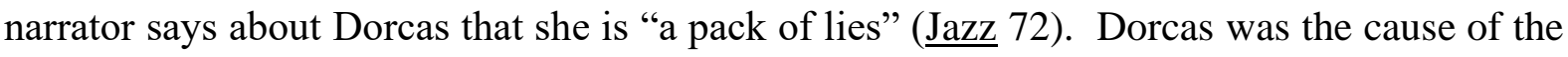
fall of herself and Joe, and by doing so she becomes one of Morrison's death-dealing characters.

The small black girl Maureen Peal was light skinned and rich in The Bluest Eye who was one of the major death-dealing characters among Toni Morrison's characters. According to Claudia, Maureen Peal was "as rich as the richest of the white girls" (The Bluest Eye 47), and Maureen showed her riches to the poor black girls and that made her have a fanciful life. She was proud that she was rich and beautiful. And she tried to compare her beauty with other girls of her age, and more of it, she used her beauty as a weapon to control other girls such as Claudia, Frieda, and Pecola. Finally she teased Pecola that Pecola saw her father's nakedness and insulted the helpless, poor Pecola. By her actions, she became a death-dealing character.

The other is the light skinned rich female Geraldine from the South in The Bluest Eye. She was clean and had some particular qualities that were absent in the ordinary blacks (native to Ohio). She followed her own methods to bring up her son Junior, and that looked mechanical which mothers do not follow usually. The narrator tells the quality of her motherhood to her only son Junior, thus,

Geraldine did not allow her baby, Junior, to cry. As long as his needs were physical, she could meet them - comfort and satiety. He was always brushed, bathed, oiled, and shod. Geraldine did not talk to him, coo to him, or indulge him in kissing bouts, but she saw that every other desire was fulfilled. It was long before the child discovered the difference in his mother's behavior to 
himself and the cat ... Geraldine was seldom away from home, and could effectively soothe the animal when Junior abused him (The Bluest Eye 67).

Further, she did not allow her son to mingle with other black children and clearly drew a line between "coloured" and "niggers" and imposed them on her son to follow. She thought that she belonged to the "cloloured" people who were better than the "niggers", according to her definition. She taught Junior the differences between the "coloured" and the "niggers" as, “... They were easily identifiable. Colored people were neat and quiet; niggers were dirty and loud" (The Bluest Eye 67). When Junior tortured Pecola with the cat and when Geraldine found out from her son's false statement that Pecola hurt the cat, Geraldine did not even think of the age of Pecola who was about the age of her son. She scolded Pecola with her usual quiet voice: "Get out ... You nasty little black bitch. Get out of my house"” (The Bluest Eye 72). Finally her upbringing that turned her only son as a big sadist that made him torture Pecola and the cat that his mother loved more than him. Clearly, Geraldine is a death-dealing character in the novel, treated not only the people of her society badly and nastily but also brought up her son with the same death-dealing qualities. Geraldine's son, Junior was another who "learned how to direct his hatred of his mother to the cat, and spent some happy moments watching it suffer" (The Bluest Eye 67). While he played with the boys, he had a habit of "push them down the mound of dirt and roll over him" (The Bluest Eye 68). Later he "enjoyed bullying girls. It was easy making them scream and run. How he laughed when they fell down and their bloomers showed. When they got up, their faces red and crinkled, it made him feel good" (The Bluest Eye 68). One day he took Pecola to his home and played with her crudely that pained her. When she tried to get out of the house, he got angry and his actions on Pecola and the cat are textured as follows:

'You can’t go out. You're my prisoner' 
He pushed her down, ran out the door that separated the rooms, and held it shut with his hands. Pecola's banging on the door increased his gasping, highpitched laughter.

Junior, curious at not hearing her sobs, opened the door, and saw her squatting down rubbing the cat's back. He saw the cat stretching its head and flattening its eyes ...

Junior tried to push her away, but she grabbed the arm which was swinging the cat. They both fell, and in falling, Junior let go the cat, which, having been released in mid-motion, was thrown full force against the window. It slithered down and fell on the radiator behind the sofa (The Bluest Eye $70-71)$.

Finally, when his mother entered the room, he lied to her that Pecola hurt the cat. Basically it could be argued that the nurture of Junior made him a sadist. But, how could it be said that the small boy had had the mentality to pain others? Because he was afraid of the black (nigger) girls as said in the text: "The nigger girls he did not pick on very much. They usually travelled in packs, and once when he threw a stone at some of them, they chased, caught, and beat him witless" (The Bluest Eye 68). Hence, it is clear that Junior too is a death-dealing figure in The Bluest Eye.

The West Indian, light brown skinned high-class-white educated preacher who proclaimed himself as "Reader, Advisor, and Interpreter of Dreams" (The Bluest Eye 130 131) was Soaphead Church. He thought "God had done a poor job, and Soaphead suspected that he himself could have done better" (The Bluest Eye 137). He is another death-dealing character who not only made use of Pecola to kill the dog that he did not like, but also abused small black children in the place where he lived. Though he was educated and had a few 
good qualities, he did all nasty things that were always death-dealing. The word "misanthrope" that he learnt made him inquire about more misanthropes of the ages and thus, ... he found misanthropy an excellent means of developing character: when he subdued his revulsion and occasionally touched, helped, counseled, or befriended somebody, he was able to think of his behavior as generous and his intensions as noble (The Bluest Eye 130).

Further, he did not like to have human relationship. Rather he wanted to have things. As in Martin Buber's relational term the I-IT relationship, Soaphead Church liked to have things as the text describes his nature:

All his life he had had a fondness for things ... a genuine love of worn objects: a coffee pot that had been his mother's, a welcome mat from the door of a rooming house he once lived in, a quilt from a Salvation Army store counter ... This thirst for worn things led him to casual but habitual examinations of trash barrels in alleys and wastebaskets in public places ... (The Bluest Eye 131).

He did not have any interest in heterosexuality nor in homosexual intercourse, and since he did not experience "sustained erection", sodomy was out of question. His attentions, therefore, directed towards children as the following passage describes:

His attentions therefore gradually settled on those humans whose bodies were least offensive - children. And since he was too diffident to confront homosexuality, and since little boys were insulting, scary, and stubborn, he further limited his interests to little girls. They were usually manageable and frequently seductive. His sexuality was anything but lewd ... (The Bluest Eye 132). 
He piked small girls' breasts. He used Pecola to kill the dog that was clean and quiet but mangy. He thought that killing the mangy dog was euthanasia and a humane act, and later in his letter to God he insisted that his acts were noble and humane. When Pecola came to him in order to get her expected bluest eyes, he first sympathized with her, and later found that she was the apt one to carry out his mission - to kill the dog that he disliked - and he gave false information that if the dog reacted to the food that she gave, then it was a miracle and God listened to her prayers. By doing so, he pushed the poor girl Pecola into madness and that became her fate finally. By doing so Soaphead Church becomes a death-dealing character who had his high fascination rather towards things than humans.

Hannah Peace was a black female character in the novel $\underline{\text { Sula. }}$ She was the mother of the eponymous character Sula. Her bedevilment made Sula become a character of her own and Sula's falls started from it. According to Nel, Sula's friend, "Hannah, never scolded or gave directions" (ula 29) to Sula whilst Hannah was just opposite of the MacTeers in $\underline{\text { The }}$ Bluest Eye who parented their children in a perfect way. Sometimes the MacTeers scolded and even beat their children and those rigours made Claudia and Frieda become good humans. This death-dealing quality of Hannah created a chaos in Sula's mind. Hannah had a good mother, Eva Peace, but unfortunately Sula did not have a good mother. Hannah loved men except her father BoyBoy, as her mother Eva did. She had many male-friends and all of them had death-dealing qualities, according to the narrator of the novel:

Hannah simply refused to live without the attentions of a man ... had a steady sequence of lovers, mostly the husbands of her friends and neighbors ... But since that crowded house there were no places for private and spontaneous lovemaking, Hannah would take the man down into the cellar in the summer where it was cool back behind the coal bin and the newspapers, or in the 
winter they would step into the pantry and stand up against the shelves ... (Sula 42-43).

This death-dealing tendency made Sula adopt her mother's way that took her close and the only friend Nel's husband who abandoned Nel with the children behind her after Sula developed an affair with him. The death-dealing quality of Hannah came out as the text brings out as follows:

Hannah's friendships with women were, of course, seldom and short-lived ... She could break up a marriage before it had even become one - she would make love to the new groom and wash his wife's dishes all in an afternoon. What she wanted ... and what she succeeded in having more often than not,

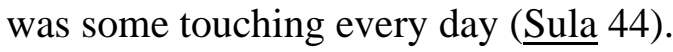

Finally, the following words of Hannah to her friends in a conversation disturbed Sula the most: “"... I love Sula. I just don't like her'” ( words of Hannah that a mother is not expected to say to her children. Thus, Hannah becomes a death-dealing character.

The rich white female Margaret in Tar Baby is another death-dealing character who not only hated her husband but also her death-dealing actions made her son go away from her. From her childhood she fantasized a romantic life, as it was evident that romantic fantasies are always destructive as in the case of Pauline Breedlove in The Bluest Eye. She wanted others to envy her beauty as follows:

... she discovered at the same time that all of South Suzanne was overwhelmed by her astonishing good looks. She agreed, finally, with their evaluation, but it didn't help much because it meant she had to be extra nice to other girls to keep them from getting mad at her. It meant having teachers go 
fuzzy in her presence (the men with glee, the women with distrust), fighting off cousins in cars ... (Tar Baby $81-82)$.

This beauty caring quality could be seen at the time when Son met her to apologize where she was over fifty at that time. She took a sunbath at the backyard of her house with the accents of a young girl. Whilst Son talked with her, she was proud that her son Michael looked like her; "Michael is every bit as tall as Valerian, but he does look more like me. Inside though, that's where he's really beautiful" (Tar Baby 199). More than anything else, Margaret tortured her son Michael, when he was a very small boy who even did not know how to express his pain to his father. Margaret pinned on Michael's backside and even burnt him with cigarette stabs. How could anyone expect any mother to act like Margaret? She did not even feel sorry for her actions on her son, and at a later stage she justified her actions to her husband Valerian as follows:

“... I was more successful in keeping myself from doing it than not. When it did happen, it was out of my control. I thought at first it was because he was crying or wouldn't sleep. But then sometimes it was in order to make him cry, or to wake him from sleep ... I have done it, lived with it ... I did it because I could, Valerian, and I stopped doing it or wanting to do it when I couldn't ... Yes, couldn't. When he was too big, when he could do it back ..." ( $\underline{\text { Tar Baby }}$ $239-240)$

Margaret reiterated when she met Ondine after their fight at the dinner table on the particular Christmas Day. Though Ondine might have said that Margaret hurt her husband's son and she loved her son, it is not at all acceptable that the mother hurts her son in order to avenge her husband. Certainly Margaret is a death-dealing character in every aspect. 
All the characters of Toni Morrison either have positive or negative attitudes towards life. They not only confine themselves to those attitudes, but also do influence others with their qualities directly or indirectly. There is only a very thin line that shows the differences first between life-affirming/life-affording and positive attitudes; secondly between lifedenying/death-dealing and negative attitudes. Life-affirming/life-affording mainly deal with the actions of the characters and their approaches towards the world, especially towards their society and its members, whereas positive attitudes mean the optimistic approaches of the characters towards their own lives as well as towards the other characters and finally towards the society as in the case of the characters Blue Jack and M'Dear in The Bluest Eye, and the Tommy Brothers and First Corinthians in Song of Solomon. Likewise, life-denying/deathdealing mainly deal with the actions of the characters and their approaches as in the case of life-affirming/life-affording qualities, whereas negative attitudes mean the pessimistic approaches of the characters towards society and the world and vice versa as in the case of the negative reaction of the Bluestone society towards Sethe (that literarily excommunicates her) in Beloved and the character Sula's attitudes (that literarily excommunicates the society from her behaviours) towards society and the world in Sula.

The three black prostitutes China, Poland, and Miss Marie in The Bluest Eye had a lot of affinity towards the poor black ugly girl Pecola, and Miss Marie told stories to Pecola to make her happy, knowing that Pecola was innocent. Further, the three prostitutes were happy and made the right man happy;

... knowing full well she was cut out for better things, and could make the right man happy. Neither were they the sloppy, inadequate whores who, unable to make a living at it alone, turn to drug consumption and traffic or pimps to help complete their scheme of self-destruction, avoiding suicide only 
to punish the memory of some absent father or to sustain the misery of some silent mother (The Bluest Eye 42).

They hated women who deceived their husbands and they called those women "sugarcoated whores" (The Bluest Eye 43), and they respected "good Christian colored women" (The Bluest Eye 43) who tended their family and who did not drink or smoke, and "they would sleep with their husbands, and take their money, but always with a vengeance" (The Bluest Eye 43). Clearly they have positive and optimistic approaches towards their actions irrespective of their profession.

The black, quiet, old, competent midwife, and decisive diagnostician, M'Dear, is also a positive character in The Bluest Eye. She lived near the woods and was wanted by the local people for all their illness, and when Cholly's grandmother Aunt Jimmy became ill, M'Dear came to the rescue of Aunt Jimmy, and her medicine made Aunt Jimmy regain normalcy. She did not care about their race, but she had her own way and this quality made her an optimist though she was a minor character in the novel.

The black teen-aged girl in Jazz Felice was the only friend of Dorcas. When her mother told her to find a good man to marry, she rejected the idea and told her that she first wanted to get a good job to stand on her legs and then to marry - an optimistic attitude in a young girl in the black society. When Joe Trace cried for three months for his killing of the young girl Dorcas, Felice comforted him though he was the murderer of her best friend. Her optimistic nature towards life was exposed when she talked about the zoo and the animals to Joe. The image of zoo and the animals that she used to society/world and the people were apt to the situation. She said thus, “... animals in the zoo were happier than when they were left

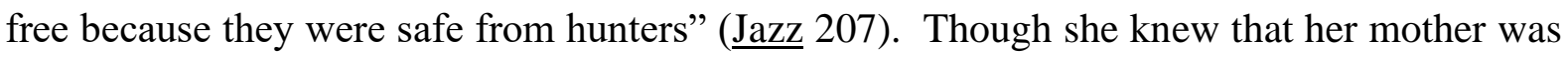
a kleptomaniac, she looked at the better side of her mother - an optimistic quality - and her remarks thus, 
My mother is so honest she makes people laugh. Returning a pair of gloves to the store when they gave her two pair instead of the one she paid for; giving quarters she finds on the seat to conductors on the trolley. It's as though she

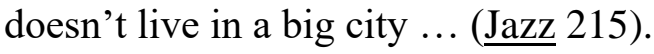

Felice compared Violet (who had excellent qualities though she tried to destroy the dead body of Dorcas) with her mother (who stole the opal ring from the stores and said that it was a present from her boss). She was an unenviable girl since she gave her ring to her friend Dorcas that had been given to her by her mother, felt happy that the ring suited Dorcas well. Felice showed her optimistic and positive qualities at the time of setting the lives of the mentally and emotionally separated couple Joe and Violet. She felt happier when she watched Joe and Violet dance together. The narrator says the positive and optimistic quality of Felice as: “... her speed may be slow, but her tempo is next year's news ..." and adds: “...she's nobody's alibi or hammer or toy” ( $\underline{\text { Jazz } 222) . ~}$

The eighteen-year-old mulatto Golden Gray is another positive character in Jazz. When he first found out from his white mother that his father was a black, he got angry and came in search of him to kill his father. But when he saw him for the first time, he lost all his rage and tried to be close to him. Further, the positive quality of his actions portrays that he not only wanted to tell his shame but also wished to share his father's sorrows. The text shows his nature as follows:

When I see him, or what is left of him, I will tell him all about the missing part of me and listen for his crying shame. I will exchange then; let him have mine and take his as my own and we will both be free, arm-tangled and whole ( $\underline{\mathrm{Jazz}}$ 159).

When his father Henry Lestory said that Golden Gray could be a free slave if he was a black (mulatto), Golden Gray replied: "'I don't want to be a free nigger; I want to be a free 
man"” (Jazz 173), and this positive and optimistic reply shows his will to be a free man, not merely a human being who could get all the basic needs.

The black eponymous girl Sula in the novel $\underline{\text { Sula, }}$ whose ideas and activities were independent, lived her life in such a way that the Medallion society did not approve at all. Sula did not approve the restricted norms of the society. When she was twelve she met Nel and befriended her. She and Nel watched the Medallion society practically and the following passage describes how they felt the Medallion society: “... each had discovered years before that they were neither white nor male, and that all freedom and triumph were forbidden to them ..." (Sula 52). This practicability to look and act on the world was very rare at the age of twelve, and Sula had it fortunately, and that gave her the strength to live in the Medallion society even if it tried to excommunicate her. When four Irish boys who were new comers to Medallion teased Nel while she was returning from school, made the frightened Nel change her route. But Sula made up her mind about Nel and took her on their usual route and frightened the boys by cutting her finger and warned them as "'If I can do that to myself, what you suppose I'll do to you?'” (Sula 52). This positive and practical act of Sula helped her friend Nel to get over the fear of those white Irish boys. The Medallion society said a story about Sula's grandmother Eva Peace when she was left away leaving three small children with her neighbour. They said that she purposefully had put her leg in a train to claim insurance. If that story was true, then it was natural for the granddaughter Sula to set the optimistic and practical way. Though it could be argued that her actions were masochistic, she used it to protect her friend. When she heard from her mother Hannah Peace that Hannah "loves" her but did not "like" her, Sula did not show her emotions towards her mother and she kept things going on without any disturbance. This is another positive quality of Sula. Further, she had control even when she was a child and that positive quality made her have free and concerning nature of others as the text illustrates her: "completely free of 
ambition, with no affection for money, property or thing, no greed, no desire to command attention or compliments - no ego ..." (Sula 119). When she returned to Medallion after ten years "accompanied by a plague of robins" (Sula 89), the Medallion society looked down on Sula that the plague of robins that accompanied her was a bad sign in their lives; but they did not harm her physically but mentally. But Sula's reaction on her society was cool and she did not care for society. Morrison might have used the image robin to show the society that Sula was free of anything, but the society took it otherwise. Though to the naked eye it may seem that the Medallion society outcast Sula, actually Sula outcast the Medallion society, and till her death the society looked at her as an outcast. The other positive and optimistic quality of Sula was told by Nel as follows: "Sula never competed; she simply helped others define themselves. Other people seemed to turn their volume on and up when Sula was in the room. More than any other thing, humor returned" ( $\underline{\text { Sula } 95) . ~}$

When Jude, Nel's husband told about some problem in his job, Sula gave a long explanation on loving for themselves first and then for their white brothers which exactly echo universal brotherhood. Sula's lengthy advice to Jude Greene shows how to love his race and the whites as follows:

... everything in the world loves you. White men love you ... And white women? They chase you all to every corner of the earth, feel for you under every bed. I knew a white woman wouldn't leave the house after 6 o'clock for fear one of you would snatch her. Now ain't that love? ... Even little children - white and black, boys and girls - spend all their childhood eating their hearts out 'cause they think you don't love them. And if that ain't enough, you love yourselves. Nothing in this world loves a black man more than another black man. You hear solitary white men, but niggers? Can't stay away from one another a whole day (Sula $103-104)$. 
More than anything else, Sula indirectly united and improved the lives of the Medallions; and it has to be considered a positive and optimistic approach. The unification and improvement of Medallion by Sula were, thus, "They began to cherish their husbands and wives, protect their children, repair their homes and in general band together against the devil in their midst" (Sula $117-118)$. Sula said that she did not know how to lie and that it was only to Nel she lied for the first time about her grandmother Eva Peace. Finally she declared in Sula's words that she had a satisfied life in the world: "I sure did live in this world" (Sula 143). This satisfaction comes from her positive and optimistic nature.

Helene Sabat Wright, Nel's mother was another black female character in the novel Sula. Helene had been brought up by her strict grandmother, and she too brought up her daughter in the same strict and religious manner. This was one of her positive qualities. But when she was married and came to Medallion, she led a happy life though her husband went to the Great Lake lines and was absent too often. She was a true Roman Catholic, but Medallion had no Roman Catholic churches. Helene selected the most conservative church in Medallion and followed her religion. The text quotes it as follows:

It was Helene who never turned her head in church when latecomers arrived; Helene who established the practice of seasonal alter flowers; Helene who introduced the giving of banquets of welcome to returning Negro veterans (Sula 18).

This quality gave her a happy life. Likewise, her son-in-law Jude Greene was a positive man in the beginning and wanted a manly job. When he heard a road was to be built to Medallion, he wanted to join and work on that road to prove his manliness. But when he found that he would not be taken in, he wanted to be the leader of his house. This optimistic quality becomes his and his wife's fate and that made him run after Sula, leaving his wife and three children. 
The white male character who did not appear physically at all, but was one of the central characters in Tar Baby was Michael. He was Valerian's and Margaret's only son who did not stay with his parents, who had been tortured by his mother in his childhood. He is an optimistic and positive character and with humane activities, he stands in the positive side of the novel. He was a white and born rich, but wished to live among the poor people in the other parts of the United States, and lived like that. He was referred to by almost all the major characters in the novel. According to his father Valerian: "His idea of racial progress is All Voodoo to the People" (Tar Baby 71). According to Jadine who adopted "white culture", Michael wanted her to apologize for this type of living as she uttered: "“He was a poet, presumably, and a Socialist; so, social awkwardness wouldn't trouble him the way it would have his father'" (Tar Baby 90). Further, his father talked about Michael's humane nature as follows:

a purveyor of exotics, a typical anthropologist, a cultural orphan who sought other cultures he could love without risk or pain ...from ghetto to reservation to barrio to migrant fare" and searches for people whom are "embarrassed to feel for themselves" and enjoys their company ... (Tar Baby 145).

Michael worked as a social worker for the Indians in Arizona [once] to stop the teenagers' suicides and encouraged the Indians to keep their heritage intact [undamaged]. All those qualities are positive and optimistic and he not only lived in that positive and optimistic way, but also urged others to live in the same way that he lived.

First Corinthians in Song of Solomon was the daughter of Macon Dead - II and elder sister to the protagonist Milkman. Though she was suppressed by her father Macon Dead II, she asked her father whilst on their car ride why coloured people could not afford to buy houses. She further listed out some of the coloured people who had houses of their own. When her sister Magdalena said that there were no coloured people who could afford two 
houses, First Corinthians optimistically replied with a list as: "'Reverend Coles can, and Dr. Singleton"' (Song of Solomon 33) at that small age. Later, at her forty fourth year, she was the first to break the boundaries of her father and went to work as a maid - though she was born rich to Macon Dead - II. She possessed a degree, yet she felt that she was unfit for making artificial dead roses, and since she was unable to find a suitable job for her education, she got the maid's job. She became slowly a practical oriented character. And "her education had taught her how to be an enlightened mother and wife, able to contribute to the civilization - or in her case, the civilizing - of her community" (Song of Solomon 188). Later she fell in love with a black tenant of her father and a daily wage-earner Henry Porter, and she was the first to leave from the golden cage of her father. She was positive and optimistic and further, she was the first before Milkman to come out form the golden cage and lived her own life with Henry Porter even after the threats from her father and brother. By doing so, she becomes a positive character.

On the other side - the negative or pessimistic - Henry Washington was a black male character who is a roomer in the apartment of the MacTeers in The Bluest Eye. The first incident broke out when Claudia asked Pecola and Frieda about a magazine that he read as follows: "'You want to go up to Mr. Henry's room and look at his girlie magazines?"” (The Bluest Eye 18). That was because he had a habit of reading pornographic magazines which is clearly a negative quality. Another incident was that he spent time with the prostitutes China and Miss Marie. According to Claudia:

... we heard voices and laughter. We looked into the living-room window, expecting to see Mama. Instead we saw Mr. Henry and two women. In a playful manner, the way grandmothers do with babies, he was sucking the fingers of one of the woman ... We knew immediately who they were, and our 
flesh crawled. One was China, and the other was called the Maginot Line (The Bluest Eye 59).

Claudia and Frieda called one of the three prostitutes Miss Marie as Maginot Line. He met Claudia and Frieda after sending those prostitutes. He told those small girls while exploiting their tender mind:

"Those were some members of my Bible class. We read the scriptures together, and so they came today to read with me ... Bed' not to mention it to your mother. She don't take to so much Bible study and don't like me having visitors, even if they good Christians" (The Bluest Eye 61).

One day Frieda complained to Claudia and later to their mother that Henry tried to abuse Frieda. The dialogue between Frieda and Claudia went thus:

'He ... picked at me.'

'Picked at you? You mean like Soaphead Church?'

'Sort of.'

'He showed his privates at you?'

'Noooo. He touched me.'

'Where?'

'Here and here.' She pointed to the tiny breasts ... (The Bluest Eye 76). That picking made Frieda's mother beat him up with a broom, their father shot him on his leg and Henry ran away from their house. That is, Henry Washington is a negative character and he exploited the small children too.

Likewise, the other minor black male character in the same novel was Samson Fuller who was Cholly Breedlove's father. Samson's negativity lied first when he did not marry Cholly's mother. When he learnt that she was pregnant, he ran away from her and that made her leave the infant on the railroad. Secondly, when Cholly in his later age tried to meet him 
after a long and tiresome effort, Samson did not even recognize his first son, and said angrily to Cholly: "Tell that bitch she get her money" (The Bluest Eye 123), thinking that Cholly belonged to some other woman whom he had fathered, and he continued his card game. The same way Cholly happened to meet a fifteen or sixteen year old boy Jake who attended Cholly's grandmother's funeral and who was one of Cholly's cousins. At that time Cholly was too small. Jake offered a cigarette to him and made Cholly smoke. Later, Jake introduced the habit of womanizing to Cholly that made Cholly have his nasty future. In the essay "The Bonds of Love and the Boundaries of Self in Toni Morrison's Beloved" in Contemporary Literature, Barbara Schapiro argues:

The violation or murder of children by their parents ... Cholly raping his daughter in The Bluest Eye ... and these cases too acts are incited by feelings of love. If the infant is traumatically frustrated in its first love relationship, if it falls to receive the affirmation and recognition it craves, the intense neediness of the infant's own love becomes dangerous and threatening (304 $305)$.

Clearly, those negative and pessimistic acts are initiated by Cholly's cousin Jake, and Jake becomes another negative character.

BoyBoy is a minor black male character in Sula who is Eva Peace's husband. He abandoned her with three small children. He met Eva after three years with another female, and he did not even ask anything about Eva's lost leg nor did he ask about his children. The text describes him as, "womanizing best, drinking second, and abusing Eva third" (Sula 32). Those are his negative qualities. Further, the male black character Shadrack in the same novel is another negative and the most pessimistic character. He suffered from trauma in the war, and was admitted to a hospital. Immediately after being discharged from the hospital he went out and cried in an open place. When he came back to Medallion, he feared the 
unexpected death: "He knew the smell of death and was terrified of it, for he could not anticipate it. It was not death or dying that frightened him, but the unexpectedness of both" (Sula 14). Thinking of death is evil and it is a negative quality of any human being according to psychiatrists. Since that thought would slow down the love and the grip to live in the world. Hence, when a person loses her/his grip, she/he will automatically deny the opportunities which face her/him and thus influence others as well in her/his way. Shadrack did it. This urged him to establish the "National Suicide Day" in Medallion where on every $3^{\text {rd }}$ of January he walked through the streets of Bottom with a cowbell and a hangman's rope calling the people, "... that this was their only chance to kill themselves or each other" (Sula 14). He not only seduced himself, but also urged others to commit suicide and influenced others to murder. At the end of the novel most of the Medallions commited suicide, following Shadrack. Clearly, Shadrack is a negative and pessimistic character.

Jadine in Tar Baby was a young black female. Though she had many positive and optimistic qualities, she urged Son to follow her way and finally that ended in a mess in the life of Son. The beginning of the novel evidences that she did not care about anyone in the supra market. When she was orphaned at the age of twelve, Sydney and Ondine took her and brought her up with the financial help of Valerian. Later, when she met Ondine, her adopted mother and niece, Jadine did not want to take care of the old Ondine and Sydney. When Ondine tried to tell her indirectly to take care of them at their old age, Jadine thought that parenting those old people was impossible, and she said through her interior monologue as: "I can't parent now. I cannot be needed now. Another time, please. I have spent it all. Please don't need me now" (Tar Baby 282). Further, when Ondine tried to explain Jadine how a perfect woman should be, Jadine did not agree with Ondine and explained her feministic way of womanhood as follows: 
'There are other ways to be a woman, Nanadine ... Your way is one, I guess it is, but it's not my way. I don't want to be ... like you. Wait. Don't look at me like that. I'm being honest with you now and you have to listen! I don't want to learn how to be the kind of woman you're talking about because I don't want to be that kind of woman' (Tar Baby 284).

It might seem that Jadine wanted to be independent and optimistic, but the overall view is that Jadine did not want to take care of the old people Sydney and Ondine who brought her up from her childhood. Then Jadine tried to tell the importance of money in the world - the typical I-IT relationship - to Son who did not agree with her. She advised him as follows:

Not even your original dime. It's not romantic. And it's not being free. It's dumb. You think you're above it, above money, the rat race and all that. But you're not above it, you're just without it. It's a prison, poverty is (Tar Baby 172).

The above advice might be practical, but it also showed her longing for money. Those were the negative qualities of Jadine. Though she was a major character in the novel, she had those negative and pessimistic qualities that made her a negative character.

Finally the Bluestone society in the novel Beloved had negative and pessimistic approaches towards Sethe who killed her daughter in order to avoid slavery. When Sethe was released from jail, she was not given any welcome. Instead, she was made an outcaste in society. When Sethe's mother-in-law Baby Suggs (the one people adored much in the Bluestone society) died, people in the place did not even eat the post-funeral food that Sethe arranged. They ate the food that they brought from their homes. Think of the emotional and physical separation that the society made on Sethe! She had been physically separated from her daughter and later haunted by the dead daughter Beloved. Her emotional attachment made Sethe starve. Later she was taken care of by her last daughter Denver. Sethe lived only 
with her last daughter Denver in 124, Bluestone Road. People who should comfort Sethe, tried to excommunicate her. Though at the latter stage they tried to help her with food and other basic needs and exorcism, they did it neither for Sethe nor for Denver, but it was the request of Lady Jones that made them help Denver. And, it was Paul D who came to the rescue (emotionally and physically) of Sethe, not the Bluestone society. That is to say, not only Toni Morrison's individual characters are negative and pessimistic but also the societies become sometimes negative and pessimistic. As Doreatha writes in "Song of Solomon: The Struggle for Race and Class Consciousness": "Toni Morrison's literary canon is a testimony to the principles of dialectics; it develops; it is interconnected; it reveals contradictions; and it reflects quantity and quality. Her canon also substantiates the promise that literature is a reflection of the society in which it is produced" (50).

On the whole, there are contradictions between the bio-centric, life-affording, positive characters and the necro-centric, life-denying, death-dealing, and negative characters. But finally the former category leads and dominates the latter ones.

Morrison is a Vitalist

In her fiction, then, Morrison has united her theme, the exploration of love, and a traditional device, the initiation motif, along with a series of brilliantly dramatized foreshadowing events, skillfully made frames, and splendid characterizations. The resulting novels are compelling statements of the failure of human values. The inversion of a traditional motif - that is, the treatment of failed initiation - is successful, its effect devastating. The achievement is remarkable, making it clear that Toni Morrison is, indeed, a major American novelist (563). The above remarks of Bakerman's on Morrison “Failure of Love: Female Initiation in the Novels of Toni Morrison" show that Toni Morrison is not a female writer nor does a black writer, but an American writer who writes for all the human beings. The Merriam-Webster Dictionary in its 2001 edition defines vitality as follows: "the 
property distinguishing the living from the nonliving" and "enduring quality." Accordingly, Morrison concerns all the living forms, an enduring quality, and she takes it a challenge to show her readers that the entire world is moving with love, care, and mutual understanding. Encyclopædia Britannica defines "vitalism” as, “....attempts (in opposition to mechanism and organicism) to explain the nature of life as resulting from a vital force peculiar to living organisms and different from all other forces found outside living things. This force is held to control form and development and to direct the activities of the organism ...."

Morrison's characters conflict at various levels. For instance, there are conflicts among workers, between lovers, friends, within families, within communities, between individuals and communities, etc. It is clear that these conflicts do not focus only on females, or the blacks, or Americans. Morrison extends these conflicts between the blacks and the whites, and certain conflicts take place outside America, and there are conflicts between the whites and the whites too - both directly and indirectly. But all these conflicts clearly pass one single message, "love."

Pecola's identity quest for "blue eyes" also tells the readers that the existing beauty within every individual is the maximum and no one can have anything outside that expecting beauty - both internally and externally. Denise Heinze reinforces the same above statement in "Beauty and Love: The Morrison Aesthetic" as follows:

By fictionalizing black and white pain alike, Morrison reveals the universally destructive power of textbook beauty. No human being is capable of physical perfection; thus, all are doomed to varying degrees of self-hatred. That there is more darkness than light in Morrison's novels is testimony to her inability to reconcile a corrosive ideology and the people who embrace it. (24-25).

Likewise, Jadine is another form of Pecola who finds out her beauty, but still identified it with the "textbook beauty." Here, Jadine is successful in achieving her beauty, hence she 
was able to become a successful model among the whites, if not in the US but at least in Paris. Thus, Morrison wants her readers that beauty is not a deciding factor for any kind of identity. This is a universal fact and Morrison gives it through her characters.

For the class struggle within communities, Morrison takes Macon Dead - II and Pilate Dead, his own and sole sister in Song of Solomon. Morrison beautifully handles this class struggle to the universal fact that loves one another, not money, is the important vital factor to any human soul. Macon Dead - II, the black rich realtor, conflicted with Pilate Dead, his black poor bootlegger sister, for many reasons. Macon Dead - II wanted to maintain his "standard" and his only relationship was with money. He calculated everything and looked everyone in terms of money. But the readers are aware at the end of the novel how Macon Dead - II realized his relationship with money. Morrison tells her readers that the live relationship is the only thing that would give life to the human beings. Dolan Hubbard reinstates this point in the essay “In Quest of Authority: Toni Morrison's Song of Solomon and the Rhetoric of the Black Preacher" as follows:

Morrison makes the connection between sermonic discourse, selfdetermination, and spiritual authority as she engages in a progressive dialectic between memory (Pilate) and forgetting (Macon). The sermonic rhetoric is not only the leavening which opens up the narrative, but it also enables Morrison to shift her focus from I-It to I-Thou relationships (289).

Morrison does not stop her love and care to human beings. She extends them even to the animals and insects. The Africans live with the nature and they preserve nature for their living. The idea gets into the mind of Morrison. In Tar Baby Valerian Street's house had a garden and he loved the plants in it. But Valerian was irritated by the soldier ants and at times he killed them by using a kind of pesticide. When Son arrived at that house, being a 
black and wanted to preserve the black culture, he did not want to kill the ants. The dialogue between Valerian and Son was as follows:

'What is the matter?'

'Ants' he said.

'Oh dear. You're let them in, and I am out of thalomide.' Said Valerian stood up. 'Over there, that can. Spray the doorsill. It won't do much good, but it will help for a while, and tuck that muslin in tighter.'

The man did as he was told and then said, 'You ought to get mirrors.'

'Mirrors for what?'

'Put outside the door. They won't come near a mirror.'

'Really?'

'Yeah,' he said and sprayed some of the ant killer on his legs. (Tar Baby 148).

Son did not want to kill the ants, though they harmed him. Instead he sprayed the ant killer on his legs that shows how he wanted to preserve nature. The ants might symbolize something else as well, but the very act of Son is important here. The same way True Belle in Jazz had a cat. She named the cat King. Golden Gray, a prominent character in Jazz, recalled True Belle's way of bringing the cat as, “... the pillow True Belle made for King to sleep on at her feet. She had been given the name of a powerful male dog, but she was a cat without personality, which is why True Belle liked her and wanted her close by" (Jazz 152). She was a servant maid to the white lady Miss Vera Louise. What is important here is that, True Belle wanted to name her cat as a "male dog", to give the cat the same courageous personality like a dog. By the way of these illustrations, it is clear that Morrison does extend her love and care to animals and insects too. That is, Morrison's vital nature does not stop with humans and society, instead she has the same quality of vitality towards other livings too. This is an extension form I-It relationship to I-Thou relationship. 
Morrison employs conflict as a tool. It is a tool that helps Morrison to show her ability of being a good vitalist. That is to say, there are a lot of conflicts among various levels such as; between generations, between genders, between classes, between races, and between individuals and the community and vice versa. But they all lead to a final conflict, that is, conflict between the bio-centric versus the necro-centric. The terms bio-centric and necro-centric are used to indicate vitalism and anti-vitalism. That is, the final conflict is nothing but the conflict between the vitalists and the anti-vitalists. It is very clear that finally the anti-vitalists are defeated. Thus, Morrison proves all her readers that vitalism is the only cause for winning the hearts of the human beings and all the living things in the world.

Morrison might base her settings as feminine, or black, or even American. But her final goal is love, and she achieves it. As Denise Heinze says;

... Morrison suggests, in her refusal to glorify or romanticize love and beauty, that human beings, disabused of dehumanizing categories of beauty, have potential to generate an inner purpose ... with wealth or poverty, respectability or infamy. That person then is lovable as a viable and unique individual rather than as a sycophant to another's ego. Allowed the freedom to exfoliate, human beings can enter into relationships free of insecurities, jealousies, or hatred. Monogamy need not be a prison but a spiritual coupling of two individuals ... For her, love is not the exclusive property of, nor most brilliantly expressed in, marriage. Love, for her, flares in the most unromantic, asexual settings and between the least likely beneficiaries ... This spiritual love between people is the essential prerequisite to communal love, a state of affairs perhaps too beautiful or a awesome for Morrison or any of us to yet imagine. (53-54). 
Thus, confining Morrison to a feminist or a black, or an American writer is inappropriate. She advocates only love that can solve all the oppositions, and it is the Universal love that becomes in all of Morrison's novels. Hence, she is a universal writer, writing for each and every one of us, and Toni Morrison is, more than anything, a vitalist. 


\section{Bibliography}

Primary Sources

Morrison, Toni. Song of Solomon. London: Vintage, 1977.

---. $\quad$ Tar Baby. London: Vintage, 1981.

---. $\quad$ Sula. New York: Penguin, 1982.

---. $\quad$ Beloved. London: Vintage, 1987.

---. $\quad$ Jazz. London: Vintage, 1992.

---. $\quad$ Paradise. London: Vintage, 1997.

---. $\quad$ The Bluest Eye. London: Vintage, 1999

Secondary Sources

Ackward, Michael. 'Roadblocks and Relatives: Critical Revision in Toni Morrison's The Bluest Eye." Mckay, Nellie. Y ed. Critical Essays on Toni Morrison. Boston: Hall, 1998.

Adams, Anne. "Straining to Make Out the Words to the 'Lied': The German Reception of Toni Morrison” Mckay, Nellie. Y ed. Critical Essays on Toni Morrison. Boston: Hall, 1998.

Barry, Peter. Beginning Theory: An Introduction to Literary and Cultural Theory. New York: Manchester university Press, 2004.

Denard, Carolyn. "The Convergence of Feminism and Ethnicity in the Fictions of Toni Morrison.” Mckay, Nellie. Y ed. Critical Essays on Toni Morrison. Boston: Hall, 1998.

Edward, Thomas R. The New York Review of Books. 5 Number, 1987

Fabre, Genevieve. “Genealogical Archeology or the Quest for Legacy in Toni Morrison's

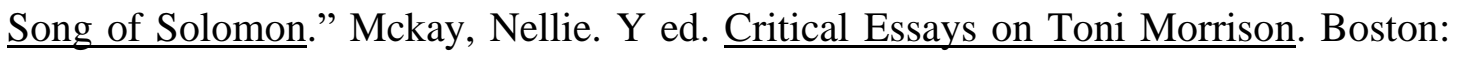
Hall, 1998. 
Horvitz, Deborah. "Nameless Ghosts: Possession and Dispossion in Beloved." Studies in American Fiction, Vol.17, No.2, Autumn 1989.

Loomba, Ania. Colonialism/ Pastcolonialism. London: Routledge, 2003.

Morrison, Toni, Playing in the Dark. NY: Random House, 1988.

Schapiro, Barbara. "The Bounds of Love and the Boundaries of Self in Toni Morrison's Beloved." Contemporary Literary Criticism, vol. 87.

Thurman, Judith. The New Yorker, 2 November, 1987.

Wessling, Joseph K. "Narcissim in Toni Morrison's Sula." CLA Journal, vol-31, no-05, 1988.

"vitalism." Encyclopædia Britannica. Encyclopædia Britannica 2006 Ultimate Reference Suite DVD.

"Vitality". Merriam-Webster Dictionary, ver. 2.1, 2001.

Works Consulted

Booth, Wayne C. The Rhetoric of Fiction. Chicago: The University of Chicago, 1961.

Buber, Martin. I and Thou. Translated by Ronald Gregor Smith. New York: Charles Scribner's Sons, 1958.

Butler, Elliott and Evans. Race, Gender, and Desire: Narrative Strategies in the Fictions of Toni Cade Bambara, Toni Morrison, and Alice Walker. Philadelphia: Temple University Press, 1989.

Eagelton, Terry. Ideology: An Introduction. New York: Verso, 1996.

Evans, Mari, ed. Black American Writers (1950 - 1980): A Critical Evaluation. New York: Anchor-Doubleday, 1984.

Hawkes, David. Ideology. London: Routledge, 2003. 165.

Joyner, Louisa. Toni Morrison - The Essential Guide. London: Vintage, 2003. 
Nevins, Allan, Henry Steele Commager and Jeffrey Morris. A Pocket History of the United

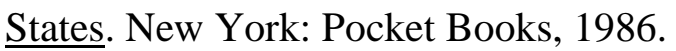

Petrson, Nancy J. ed. Modern Fiction Studies. Vol.-39, Issue - 3 \& 4, Fall/Winter - 1993.

Smith, Valerie. Self-Discovery and Authority in Afro-American Narrative. Cambridge: Harvard University Press, 1987. 